JURNAL NOMOSLECA

Volume 3, Nomor 2, Oktober 2017

\title{
STRATEGI KOMUNIKASI PERSUASIF DALAM MENINGKATKAN MOTIVASI BELAJAR SISWA
}

\author{
Nisful Laily Zain \\ Kepala SMK PGRI 1 Pasuruan \\ anislailyzain2@gmail.com
}

\begin{abstract}
Abstrack
This research was conducted to find out what kind of personal communication strategy of teachers to improve student learning motivation in SMK JAWARA PGRI 1 Pasuruan. This research method using single case study with qualitative descriptive approach. This research is done by using object observation and interview to various informants that are directly related. From the research, it was found that personal communication done by the teacher to students and guardians, parents have a significant role in improving students' learning motivation. Personal communication approaches to students and parents need more seriousness and diligence than for teachers, because it takes up more energy, time, energy and also the cost necessary to communicate personally.
\end{abstract}

Keywords: Personal communication, motivation, seriousness.

\begin{abstract}
Abstrak
Penelitian ini dilakukan untuk mengetahui seperti apa strategi komunikasi personal para guru untuk meningkatkan motivasi belajar siswa di SMK JAWARA PGRI 1 Pasuruan. Metode penelitian ini menggunakan studi kasus tunggal (single case study) dengan pendekatan kualitatif deskriptif. Penelitian ini dilakukan dengan menggunakan observasi objek dan wawancara kepada berbagai informan yang terkait secara langsung. Dari penelitian yang dilakukan diperoleh hasil bahwa, komunikasi personal yang dilakukan oleh guru kepada siswa maupun wali siswa, orang tua siswa memiliki peran signifikan dalam meningkatkan motivasi belajar siswa. Pendekatan komunikasi personal terhadap siswa dan orang tua siswa perlu keseriusan dan ketekunan dari pada guru, sebab menyita lebih banyak energi, waktu, tenaga dan juga biaya yang diperlukan untuk menjalin komunikasi secara personal.
\end{abstract}

Kata Kunci: Komunikasi personal, motivasi, keseriusan. 


\section{PENDAHULUAN}

Dalam proses pendidikan, belajar merupakan kegiatan yang paling utama. Artinya berhasil atau tidaknya pencapaian tujuan pendidikan ditentukan oleh proses belajar dan pembelajaran siswa di sekolah tersebut. Sedangkan keberhasilan belajar seseorang dipengaruhi oleh banyak faktor di antaranya adalah motivasi siswa tersebut dalam belajar. Kenyataan di lapangan, banyak dijumpai siswa belajar karena terpaksa menuruti kemauan orang tua atau karena merasa memiliki kewajiban untuk belajar, atau juga karena malu jika tidak belajar atau mengenyam pendidikan. Kondisi belajar yang demikian bukan karena kebutuhan, sehingga kegiatan belajar tidak dilakukan dengan sepenuh hati, atau sekedarnya saja, asal dikerjakan. Hal ini berdampak pada hasil yang diperoleh menjadi tidak maksimal.

Padahal, motivasi memegang peranan yang penting dalam proses belajar. Apabila guru dan orang tua dapat memberikan motivasi yang baik pada siswa dan anaknya, maka dalam diri siswa atau anak akan timbul dorongan dan hasrat untuk belajar lebih baik. Memberikan motivasi yang baik dan sesuai, maka anak dapat menyadari akan manfaat dan tujuan yang hendak dicapai dengan belajar. Motivasi yang tepat dan berhasil akan memacu dan memicu siswa untuk lebih giat lagi dalam belajar.

Motivasi yang muncul dalam diri setiap siswa akan meminimalisasi kelemahan dan rasa bosan atau suasana yang tidak nyaman, dalam belajar. Sehingga, mungkin saja siswa yang karena siswa kurang motivasi baik dari dalam diri sendiri maupun dari luar dirinya yakni kondisi keluarga, orang tua maupun lingkungan belajar, akan terkikis dengan sendirinya.

Secara rinci dapat dijelaskan hal hal yang menyebabkan siswa mengalami kesulitan dan masalah dalam belaja. Hal ini diperkuat dari hasil penelitian yang dilakukan oleh Inayah, dkk (2013) seperti tidak adanya motivasi untuk belajar, mereka tidak bersemangat dan tidak mau untuk datang kesekolah, tidak bergerak aktif dan bermalas-malasan dalam kelas, antara lain adalah: a) faktor psikologis seperti intelegensi, bakat, minat, kematangan dan motivasi. Motivasi murid dalam proses belajar hendaknya diperhatikan guru, sebab motivasi erat sekali hubungannya dengan tujuan belajar, bila murid tidak mempunyai motivasi dalam belajar tentu prestasi belajar akan menurun, b) faktor yang bersumber dari lingkungan sekolah dapat menimbulkan kesulitan belajar yaitu kurikulum, metode belajar, hubungan guru dengan guru, hubungan murid dengan guru, hubungan murid dengan murid serta sarana prasarana. Metode mengajar guru yang tidak tepat digunakan dalam pembelajaran mampu menurunkan motivasi belajar siswa. c) faktor yang bersumber dari lingkungan keluarga yaitu ekonomi keluarga, hubungan sesama keluarga, tuntutan orang tua, pendidikan orang tua, dan lain-lain. d) Faktor lingkungan masyarakat dapat menimbulkan menurunnya motivasi belajar seperti media elektronika, ponsel, buku-buku pornografi dan lain lain.

Fenomena yang terjadi akhir akhir ini di kalangan pelajar sangat memprihatinkan. Seiring dengan pesatnya perkembangan kemajuan teknologi dan ilmu pengetahuan selain membawa dampak positif bagi mereka ternyata juga menimbulkan dampak negatif. Canggihnya 
alat-alat komunikasi menyuguhkan tawaran tawaran yang mengiurkan bagi anak anak seusia mereka. Kenakalan remaja yang makin meningkat menjadikan orang tua, pihak sekolah, masyarakat semakin kuatir. Kasus-kasus pelecehan seksual, video porno, bolos sekolah dan gengster makin marak terjadi.

Jika dilihat lebih jauh dan mencermati sebenarnya siswa bermasalah di sekolah adalah rangkaian dari mata rantai permasalahan-permasalahan yang mereka hadapi di rumah. Sekolah sebagai tempat kedua adanya interaksi dan aktivitas yang melibatkan remaja usia sebaya. Secara Psikologis kepribadian mereka masih labil. Kondisi demikian menyebabkan anak akan mengalami kesulitan dalam proses pembelajaran yang menimbulkan dampak bagi dirinya dan sekolah tersebut, untuk itu seorang guru harus mengetahui dan membantunya untuk lebih mendorong atau memotivasi.

Menurut pendapat Makmum dan Surya (Riduan, 2009: 20) guru sebagai motivator bagi siswanya harus mampu untuk (1) meningkatkan dan memeberikan dorongan siswa untuk belajar (2) menjelaskan secara kongkrit kepada siswa apa yang dapat dilakukan pada akhir pelajaran (3) memberikan ganjaran untuk prestasi yang dicapai dikemudian hari (4) membuat regulasi (aturan) perilaku siswa. Dalam kegiatan belajar-mengajar, motivasi sangat diperlukan. Hasil belajar siswa akan menjadi optimal bila ada motivasi. Hal ini sejalan dengan pendapat Halwey yang mengatakan bahwa para siswa yang memiliki motivasi tinggi, belajarnya lebih baik dibandingkan dengan para siswa yang motivasinya rendah.

Motivasi merupakan jantungnya proses belajar, maka tugas guru yang utama adalah bagaimana membangun motivasi siswa terhadap apa yang dipelajari. Siswa yang termotivasi dalam belajar menunjukkan minat kegairahan dan ketekunan dalam belajar tanpa tergantung banyak pada guru.

Berbagai upaya guru dalam memotivasi siswa dapat dilakukan, salah satunya adalah pendekatan personal/ pendekatan pribadi (personal approach). Pendekatan personal merupakan pendekatan langsung yang dilakukan oleh guru terhadap anak didiknya untuk memecahkan masalahnya, diberikan perhatian khusus dibandingkan dengan siswa yang lain. Dalam hal ini guru atau pendidik dituntut yang namanya "kesabaran" dan juga menyita waktu yang cukup banyak, diperlukan komunikasi yang intens dalam bentuk pendampingan pendampingan. Dengan pendekatan secara personal kepada siswa ini diharapkan dapat digunakan untuk mengatasi "siswa bermasalah" di sekolah.

Pendekatan personal pada siswa dapat dilakukan oleh guru kelas, guru mata pelajaran maupun guru bimbingan konseling. Masing masing guru dituntut untuk memiliki kemampuan dan keahlian untuk membimbing siswa yang bermasalah dengan caranya masing masing.

Pendekatan personal adalah salah satu cara yang efektif yang dapat digunakan untuk membantu para siswa dalam menghadapi permasalahannya. Untuk mengetahui lebih jauh bagaimana peran personal approach dalam meningkatkan motivasi belajar siswa, strategi personal approach seperti apa yang bisa meningkatkan motivasi belajar siswa dan apa hambatan dan tantangan dalam menerapkan personal approach maka penulis melakukan sebuah penelitian di SMK PGRI 1 Pasuruan. 


\section{TINJAUAN PUSTAKA}

\section{Strategi Komunikasi Persuasif}

Ada beragam definisi komunikasi persuasif yang dikemukakan oleh para ahli. Menurut Kamus Ilmu Komunikasi (dalam Rakhmat, 2008: 14), komunikasi persuasif diartikan sebagai suatu proses untuk mempengaruhi pendapat, sikap dan tindakan orang dengan menggunakan manipulasi psikologis sehingga orang tersebut bertindak seperti atas kehendaknya sendiri. Selain itu, komunikasi persuasif juga diartikan sebagai komunikasi yang dilakukan sebagai ajakan atau bujukan agar mau bertindak sesuai dengan keinginan komunikator (Barata, 2003:70).

Menurut Devito, usaha melakukan persuasi ini memusatkan perhatian pada upaya mengubah atau memperkuat sikap atau kepercayaan khalayak atau pada upaya mengajak mereka bertindak dengan cara tertentu. Persuasi juga dipahami sebagai usaha merubah sikap melalui penggunaan pesan dan berfokus pada karakteristik komunikator dan pendengar (Devito, 2011: 499).

Dalam Suranto (2011), komunikasi persuasif menggunakan teori yang dicetuskan oleh Wilbur Schramm 1950-an the bullet theory of communication atau teori peluru. Ia disebut pula dengan hypodermic-needle theory atau teori jarum hipodermik. Kadang-kadang disebut pula transmission belt theory atau teori lajur transmisi. Dalam teori ini dibahas mengenai pengaruh pesan yang disalurkan melalui media massa dan mengatakan bahwa media massa itu ampuh untuk mengubah perilaku massa.

Komunikasi persuasif memiliki sasaran yang berkorelasi dengan motivasi dari orang yang diajak berkomunikasi secara persuasif. Motivasi (motivation) diartikan sebagai kekuatan dorongan, kebutuhan semangat, tekanan atau mekanisme psikologis yang mendorong seseorang atau sekelompok orang untuk mencapai apa yang dikehendakinya (Danim, 2004: 2).

Dalam melakukan pendekatan komunikasi personal menurut Djamarah (2005, 165) guru harus melakukan beberapa hal diantaranya adalah:

a. Mendengarkan secara simpati dan menanggapi secara positif pikiran anak didik dan membuat hubungan saling percaya

b. Membantu anak didik dengan pendekatan verbal dan pendekatan non verbal

c. Membantu anak didik tanpa harus mendominasi atau mengambil alih tugas

d. Menerima perasaan anak didik sebagaimana adanya atau menerima perbedaannya dengan penuh perhatian

e. Menangani anak didik dengan rasa aman, penuh pengertian, dan mungkin memberikan beberapa alternatif pemecahan

\section{Motivasi Belajar Siswa}

Leavitt (1992), motivasi belajar diartikan sebagai keseluruhan daya penggerak baik dalam diri maupun dari luar siswa (dengan tidak menciptakan serangkaian usaha untuk menyediakan kondisi kondisi tertentu) yang menjamin kelangsungan dan memberikan arah pada kegiatan belajar, sehingga tujuan yang dikehendaki oleh subyek belajar itu dapat 
tercapai. Motivasi ekstrinsik bersumber atau kemunculan dari luar diri setiap orang. Motivasi intrinsik mempunyai arti seperti bunyinya, yaitu memotivasi dari dalam diri seseorang, seseorang melakukan sesuatu karena ingin melakukannya. Motivasi ekstrinsik berasal dari luar diri orang tertentu.

Hurlock menuliskan berbagai perubahan sikap dan perilaku sebagai akibat dari perubahan yang terjadi pada masa puber. Sikap dan perilaku yang dimaksudkan adalah; ingin menyendiri, bosan, inkoordinasi, antagonism social, emosi yang meninggi, dan hilangnya kepercayaan diri (1980: 192).

Dalam Sardiman (2007) interaksi kegiatan belajar-mengajar berdasarkan motivasi siswa menunjukkan minat, inisiatif dan aktif dalam kegiatan belajar. Sehingga akan terbentuk komunikasi timbal-balik antara guru dan siswa. Dengan demikian, akan diperoleh hasil yang lebih baik bagi siswa yaitu tidak sekedar ilmu pengetahuan tapi juga nilainilai yang bisa membentuk perkembangan pribadi siswa seutuhnya.

Menurut Nurihsan

pendekatan yang dilakukan kepada siswa dalam menangulangi permasalahan antara lain:

1. Pendekatan Krisis. Pendekatan krisis disebut juga pendekatan kuratif merupakan upaya bimbingan yang diarahkan kepada individu yang mengalami krisis atau masalah. Pendekatan ini bertujuan mengatasi krisis atau masalah masalah yang dialami individu, selanjutnya mereka memberikan bantuan sesuai dengan masalah yang dirasakan oleh siswa.

2. Pendekatan Remedial. Pendekatan remedial merupakan pendekatan yang diarahkan kepada individu yang mengalami kelemahan kelemahan yang dialami oleh individu. Pembimbing memfokuskan tujuannya pada kelemahan kelemahan individu dan selanjutnya berupaya untuk memperbaikinya.

3. Pendekatan preventif. Pendekatan preventif merupakan pendekatan yang diarahkan pada masalah umum individu, mencegah jangan sampai masalah tersebut menimpa individu. Guru memberikan upaya seperti informasi dan ketrampilan untuk mencegahnya.

4. Pendekatan Perkembangan. Pendekatan perkembangan menekankan kepada pengembangan potensi dan kekuatan yang ada pada pengembangan potensi dan kekuatan yang ada pada individu secara optimal. Setiap individu memiliki potensi dan kekuatan tertentu melalui penerapan berbagai bimbingan potensi, kemudian kekuatan kekuatan tersebut dikembangkan. Layanan bimbingan ini diberikan kepada setiap individu bukan hanya yang memiliki masalah.

\section{METODE PENELITIAN}

Penelitian ini menggunakan metode studi kasus, karena penelitian ini bertujuan untuk mengamati bagaimana strategi komunikasi personal yang dilakukan oleh para guru di SMK PGRI 1 Pasuruan, dapat meningkat motivasi belajar siswa. Penelitian ini menyediakan gambaran yang cukup lengkap mengenai apa yang terjadi pada saat penelitian dilakukan.

Sementara itu, desain penelitian (research design) yang dipilih dalam penelitian ini adalah single-case study dengan pendekatan kualitatif deskriptif. 
Penelitian ini dilakukan melalui pengamatan langsung (observasi) terhadap objek pada saat penelitian dilakukan dengan menggunakan observasi dan wawancara kepada pihak yang terlibat, baik dari siswa guru, maupun orang tua yang terkait langsung dengan kegiatan belajar.

Mulyana (2011) pengumpulan data dilakukan dengan cara observasi langsung oleh peneliti dan pengumpulan data juga melalui informan. Observasi dilakukan untuk melihat aktivitas dan kehidupan para siswa dan guru. Selain itu, peneliti juga melakukan wawancara langsung dengan informan kunci yang terdiri dari guru, siswa dan orang tua.

Bungin (2007) data yang diperoleh kemudian disusun dengan menggunakan teknik pengolahan data, mereduksi data, menyajikan data yang sudah diperoleh, dan menarik kesimpulan.

\section{HASIL PENELITIAN DAN PEMBAHASAN}

Komunikasi interpersonal atau komunikasi antar pribadi adalah sebuah proses interaksi antara dua orang yang dilakukan secara tatap muka (face to face) atau melalui media. Karena itu, dengan kata lain, sebuah dialog atau percakapan yang terjadi antara dua orang bersifat personal, langsung, dan akrab. Komunikasi interpersonal atau komunikasi antar pribadi yang terjadi sebagian besar bergantung pada hubungan antara dua individu, kesetaraan status, lingkungan sosial budaya di mana komunikasi terjadi, dan lain sebagainya. Komunikasi interpersonal atau komunikasi antar pribadi yang menggunakan media dalam proses pertukaran pesan biasanya disebut dengan komunikasi interpersonal bermedia.
Komunikasi interpersonal akan lebih efektif jika menggunakan komunikasi persuasif. Sebab, seorang persuader tertarik pada sikap dalam rangka kepentingannya untuk memprediksi secara persuasi, berdasarkan pengetahuan tentang variabel yang mengantarai antara dampak pesan, dan respon persuade terhadap pesan yang disampaikan.

Berdasarkan beberapa pendapat tersebut, dapat ditemukan bahwa komunikasi persuasif merupakan suatu proses di mana seseorang komunikator menyampaikan rangsangan verbal untuk mempengaruhi, mengubah pandangan, sikap dan perilaku orang lain/kelompok orang (komunikan) dengan cara membujuk. Dengan komunikasi persuasif orang akan melakukan apa yang dikehendaki komunikatornya, dan seolaholah komunikan melakukan pesan komunikasi atas kehendaknya sendiri.

Peran komunikasi persuasif akan terlihat dan akan mampu mewujudkan tujuan dari komunikasi, dalam hal ini untuk memberikan persepsi dan pemahaman tentang materi pembelajaran kepada siswa. Selain itu, komunikasi persuasif dapat menunjang kelancaran dalam pelaksanaan proses pembelajaran, yaitu mampu memunculkan motivasi belajar siswa. Sifat komunikasi persuasif yang membujuk dapat meyakinkan siswa, bahwa pembelajaran atau materi yang disampaikan sangat penting untuk dipahami. Sehingga siswa dengan sendirinya akan termotivasi untuk mempelajari materi yang diajarkan.

Dengan komunikasi persuasif, guru mampu mengajak siswa untuk berinteraksi dengan baik tanpa ada pemaksaan. Sehingga motivasi belajar akan muncul dari dalam diri siswa. Sehingga dapat disebutkan bawah, 
Motivasi dilihat dari sumbernya terdiri dari motivasi intrinsik dan ekstrinsik. Motovasi intrinsik yang bersumber atau kemunculannya dari diri setiap orang.

Untuk meningkatkan motivasi belajar siswa peran guru sangatlah penting. Keberadaan guru yang memiliki waktu cukup lama dengan siswa sangat memungkinkan guru untuk mengetahui permasalahan permasalahan motivasi belajar siswa. Strategi yang dilakukan oleh guru untuk meningkatkan motivasi belajar siswa dengan melakukan pendekatan secara personal. Dalam sebuah pembelajaran yang baik guru berperan sebagai pembimbing dan fasilitator. Dalam peranannnya sebagai pembimbing, guru berusaha menghidupkan dan memberikan motivasi agar terjadi proses interaksi yang kondusif.

Ada beberapa pendekatan yang dapat dilakukan oleh guru terhadap siswa nya yang bermasalah, dalam hal ini peneliti menfokuskan pada pendekatan personal/ pribadi pada siswa, yang berada di SMK PGRI 1 Pasuruan. Baik pendekatan kepada siswa secara langsung, maupun pendekatan dan komunikasi dengan orangtua siswa. Kedua pendekatan dilakukan dengan frekuensi dan pola yang beragam.

Pendekatan personal adalah pendekatan yang dilakukan oleh guru terhadap siswa yang bertujuan untuk membimbing dan membantu siswa secara individual. Pendekatan personal adalah suatu pendekatan yang melayani perbedaan perbedaan perorangan siswa sedemikian rupa sehingga dengan penerapan pendekatan personal memungkinkan berkembangnya potensi potensi masingmasing siswa secara optimal. Sebagai individu anak mempunyai kebutuhan dasar baik fisik maupun kebutuhan anak untuk diakui sebagai pribadi, kebutuhan untuk dihargai dan menghargai orang lain, kebutuhan rasa aman, dan juga sebagai mahkluk sosial, anak mempunyai kebutuhan untuk menyesuaikan dengan lingkungan baik dengan temannya ataupun dengan guru dan orangtuanya.

Pendekatan yang dilakukan oleh guru secara personal/ pribadi mampu mengatasi perasaan perasaan negatif yang sering muncul tak terduga dibenak siswa. Dengan pendekatan ini siswa merasa memiliki teman dan orang yang dapat dipercaya untuk membantunya dalam menghadapi masalah. Biasanya siswa lebih terbuka menceritakan permasalahan yang dihadapi, mau mendengarkan saran, menerima kenyataan dan berbuat lebih baik karena mampu mengatasi perasaannya.

Dari penelitian yang dilakukan diperoleh data bahwa permasalahan siswa yang terjadi di SMK PGRI 1 Pasuruan begitu kompleks di antaranya data paling banyak adalah pelanggaran kedisiplinan terutama pada absen siswa dan keterlambatan. Angka ketidakhadiran siswa di sekolah dan siswa yang terlambat cukup tinggi. Selebihnya pelanggaran kedisiplinan tidak mengikuti pelajaran pada mata pelajaran tertentu, terlambat masuk kelas, jajan dikantin di luar jam istirahat/ jam olahraga, merokok, tidak memakai seragam sesuai dengan jadwal yang sudah ditentukan.

Permasalahan siswa yang juga kerap kali muncul pada saat kegiatan belajar di kelas, antara lain, siswa tidak memperhatikan guru pada saat berlangsungnya kegiatan belajar-mengajar (KBM), tidur pada saat kegiatan belajar, mengaktifkan ponsel tidak tepat waktu, membuat gaduh dan kegiatan kegiatan lain yang bersifat menganggu berlangsungnya kegiatan belajar di kelas. 
Siswa di sekolah menengah berada pada fase remaja. Pada fase ini individu mengalami perubahan yang besar yang di mulai sejak datangnya fase masa puber.

Untuk menangani berbagai permasalahan siswa yang muncul di SMK PGRI 1 Pasuruan seperti yang dikemukakan di atas, ada beberapa beberapa pendekatan personal yang dilakukan oleh guru, baik oleh guru wali, guru bimbingan konseling (BK) maupun guru mata pelajaran. Komunikasi juga dilakukan tidak sama setiap siswa, beragam antara satu siswa dengan siswa yang lain, tergantung tingkat kebutuhan.

Pendekatan kepada siswa yang bermasalah dilakukan dalam bentuk pendekatan personal di mana guru yang mendapati siswa bermasalah akan melakukan pendekatan secara individu atau pribadi, guru memanggil siswa untuk berkomunikasi empat mata. Penanganan siswa yang bermasalah dilakukan dalam waktu yang tidak ditentukan baik di dalam kelas atau pun di luar kelas, kebanyakan guru melakukan pertemuan dengan siswa di ruang konseling. Dengan durasi waktu yang juga sangat bervariasi antara 15 menit sampai dengan 30 menit.

Dari data yang diperoleh melalui guru bahwa sekolah telah memiliki aturan terkait dengan prosedur penanganan permasalahan siswa, mulai dari penanganan langsung kepada siswa dengan pemangilan siswa maksimal dua kali, jika tidak ada perubahan maka akan lakukan pemangilan orang tua. Dari setiap anak yang memiliki permasalahan dan dilakukan penanganan maka guru akan terus melakukan pengamatan pada perubahan sikap dan perilaku, apakah terjadi perubahan atau tidak. Jika dalam waktu 1 minggu siswa tidak terlihat perubahan maka guru akan melakukan pemanggilan siswa kembali untuk diajak berkomunikasi, setelah pemangilan kedua guru akan melakukan pengamatan pada siswa dalam jangka waktu dua minggu. Jika dalam waktu dua minggu tidak terjadi perubahan sikap dan perilaku siswa maka guru akan melakukan pemanggilan kepada orang tua atau siswa.

Tetapi pada kasus-kasus tertentu yang sifatnya sangat prinsip seperti absen siswa, maka guru hanya melakukan pembinaan satu kali saja dengan siswa jika siswa mengulang maka guru akan langsung melakukan komunikasi dengan orang tua dengan mengundang orang tua datang ke sekolah. Komunikasi dengan orang tua akan juga terus berlanjut baik melalui tatap muka atau komunikasi dengan mengunakan telepun atau pesan pendek lewat ponsel.

Jika komunikasi dengan orang tua sulit dilaksanakan maka, guru akan melakukan kunjungan kepada orang tua (home visit) beberapa orang tua terkadang kurang respon terhadap upaya sekolah untuk menangani masalah siswa, dengan alasan kesibukan sehingga tidak bisa meluangkan waktu datang ke sekolah, maka guru akan datang berkunjung ke rumah siswa. Dengan kedatangan guru bertemu langsung dengan orang tua di rumah, maka akan semakin banyak data yang diketahui oleh guru terkait dengan masalah siswa, tidak hanya informasi yang diperoleh dari siswa atau orang tua saja, tetapi guru dapat melihat langsung kondisi keluarga baik dari keluarga, lingkungan tempat tinggal, ekonomi, sosial atau hal lain yang mungkin menjadi salah satu sebab dari munculnya permasalahan siswa.

Permasalahan siswa yang ditangani secara intens membawa dampak yang signifikan terkait dengan perubahan motivasi belajar siswa, siswa yang 
mendapatkan penanganan secara dini akan lebih muda untuk diperbaiki. Beberapa informasi diperoleh dari siswa yang bermasalah, mereka merasa senang karena mendapatkan perhatian dari guru guru. Dengan adanya pendekatan yang dilakukan oleh guru yang bermasalah terkait dengan turunnya motivasi mereka untuk belajar merasa mendapat tempat untuk mencurahkan segala permasalahan yang dirasakan, mereka tidak segan untuk berbicara kepada guru terkait dengan masalah yang dirasakan dikeluargannya yang menjadikan mereka malas untuk datang ke sekolah, kenapa mereka terlambat dan lain sebagainya. Tidak jarang pula permasalahan itu muncul dari dalam sekolah sendiri, misalnya mereka tidak menyenangi pelajaran yang ada di kelas, mereka tidak suka dengan guru yang mengajar karena dianggap tidak menarik atau juga karena sebab teman yang tidak menyenangkan buat mereka.

\section{PENUTUP}

\section{Simpulan}

Guru di SMK PGRI 1 Pasuruan menggunakan pendekatan komunikasi personal kepada siswa dan orang tua dalam menyelesaikan persoalan motivasi belajar para siswa. Pendekatan komunikasi personal memiliki nilai efektif untuk meningkatkan motivasi belajar siswa.

Komunikasi personal dilakukan secara cara yang bertahap dan berkali, tidak hanya satu kali, dan tidak satu arah. Mulai dari komunikasi personal dengan siswa dalam hitungan satu, dua, hingga tiga kali. Jika masih belum mampu meningkatkan motivasi, maka komunikasi personal akan dilakukan kepada orangtua siswa.
Dengan pendekatan personal guru dapat membantu siswa dengan cara yang tepat dan paling efektif agar siswa yang bermasalah dapat terselamatkan. Kasus kasus yang bervariatif dapat diminimalkan, setidaknya mampu dikendalikan sehingga tdak menyebar atau menular pada siswa yang lainnya.

\section{Saran}

1. Komunikasi personal dalam praktiknya tidak gampang, butuh pengorban lebih dari para guru, sebab memerlukan waktu tenaga dan pikiran yang ekstra. Sehingga membutuhkan perhatian lebih untuk dapat melaksanakannya sehingga hal ini perlu ditanggapi secara serius.

2. Kemampuan guru dalam melakukan komunikasi interpersonal terhadap siswa menjadi perhatian utama untuk meningkatkanmotivasi siswa.

\section{DAFTAR PUSTAKA}

Barata, Atep Adya. 2003. Dasar- Dasar Pelayanan Prima. Jakarta : Elex Media.

Bungin, Burhan. 2007. Penelitian Kualitatif: Komunikasi, Ekonomi, Kebijakan Publik, dan Ilmu Sosial Lainnya. Jakarta: Kencana.

Danim, Sudarwan. 2004. Motivasi Kepemimpinan dan Efektifitas Kelompok. Jakarta: Rineka Cipta.

Devito, Joseph. 2010. Komunikasi Antarmanusia, Edisi Kelima. Jakarta: Karisma Publishing Group

Djamarah, Syaiful Bahri. 2005. Guru dan Anak Didik Dalam Interaksi Edukatif: Suatu Pendekatan Teoritis Psikologis. Jakarta: Rineka Cipta.

Hurlock, Elizabeth B. 1980. Psikologi Perkembangan: Suatu Pendekatan. 
Sepanjang Rentang Kehidupan.

Jakarta : Gramedia.

Inayah, Ridaul., dkk. 2013. Pengaruh Kompetisi Guru, Motivasi Belajar Siswa, Dan Fasilitas Belajar Terhadap Prestasi Belajar Mata Pelajaran Ekonomi Pada Siswa Kelas XI IPS SMK Lasem Jawa Tengah. Jurnal Pendidikan Insan Mandiri : Vol. 01 No. 1 Tahun 2013.

Leavitt, Harold J. 1992. Psikologi Manajemen. Jakarta: Erlangga.

Mulyana, Deddy. 2011. Metode Penelitian Komunikasi. Bandung: Remaja Rosdakarya.

Nurihsan. 2006. Bimbingan dan Konseling Dalam Berbagai Latar Kehidupan. Bandung: PT Refika Aditama.

Rakhmad, Jalaluddin. 2011. Psikologi Komunikasi. Bandung: Remaja Rosdakarya.

Riduan. 2011. Belajar Mudah Penelitian Untuk Guru, Karyawan dan Peneliti Pemula. Bandung: Alfabeta

Sardiman. 2007. Interaksi dan Motivasi Belajar Mengajar. Jakarta: Rajawali Pers. 